\title{
Palynological, geochemical, and mineralogical characteristics of the Early Jurassic Liasidium Event in the Cleveland Basin, Yorkshire, UK
}

\author{
Stephen P. Hesselbo ${ }^{1 *}$, Alexander J. L. Hudson ${ }^{1}$, Jenny M. Huggett ${ }^{2}$, \\ Melanie J. Leng ${ }^{3,4}$, James B. Riding ${ }^{3}$ and Clemens V. Ullmann ${ }^{1}$
}

With 8 figures

\begin{abstract}
A previously proposed hyperthermal episode in the Early Jurassic (mid-Sinemurian) is investigated from the shallow marine succession at Robin Hood's Bay, Cleveland Basin, Yorkshire, UK. Palynological study confirms that the stratigraphical extent of the distinctive dinoflagellate cyst Liasidium variabile corresponds very closely to the oxynotum Zone. The range of Liasidium variabile also corresponds to an overall negative excursion in carbon-isotopes measured in bulk organic matter, which here exhibits a double spike in the middle oxynotum Zone. Additionally, Liasidium variabile abundances track overall transgressiveregressive facies trends with peak abundance of dinoflagellate cysts corresponding to deepest water facies and maximum flooding. Lithological cycles (parasequences), defined by visual description and hand-held X-ray fluorescence analysis of powdered samples, match previously suggested short eccentricity cycles, and allow a total duration for the event of at least one million years to be suggested. Changes in clay mineralogy throughout the section determined by whole rock X-ray diffraction and scanning electron microscopy are shown to be largely related to authigenic processes, and neither support nor refute the proposition of coeval palaeoclimate changes. The combined characteristics of the Liasidium Event described from Robin Hood's Bay are similar to, but much less extreme than, the Early Jurassic Toarcian Oceanic Anoxic Event albeit, at this locality, there is no evidence for the development of significant bottom water deoxygenation.
\end{abstract}

Key words. carbon-isotope excursion, Early Jurassic, hyperthermal, Liasidium Event, Liasidium variabile, Yorkshire

\section{Introduction}

Supposed hyperthermal events associated with perturbations to the global carbon cycle have been increasingly recognized from the geological record. It has been suggested that the Early Jurassic oxynotum Zone (Sinemurian Stage; 194 Ma) records a hyperthermal event, hereafter referred to as the Liasidium Event, similar to the well-studied Paleocene-Eocene Thermal Maximum in the Cenozoic (Riding et al. 2013). The bases for this interpretation are the synchronous abundant occurrences of the thermophilic pollen grain Classopollis classoides and the distinctive dinoflagellate cyst Liasidium variabile, together with the devel-

\footnotetext{
Authors' addresses:

${ }^{1}$ Camborne School of Mines, University of Exeter, Penryn Campus, Penryn, Cornwall TR10 9FE, UK.

2 Department of Earth Sciences, Natural History Museum, Cromwell Road, London SW7 5BD, UK.

${ }^{3}$ British Geological Survey, Keyworth, Nottingham NG12 5GG, UK.

${ }^{4}$ School of Biosciences, Sutton Bonington Campus, University of Nottingham, Loughborough LE12 5RD, UK.

* Corresponding author: s. p.hesselbo@exeter.ac.uk
} 
opment of a negative carbon-isotope $\left(\delta^{13} \mathrm{C}_{\text {org }}\right)$ excursion in bulk organic matter with an amplitude of $\sim 2$ per mil. Although the taxonomic affinities, and the stratigraphical and palaeogeographical distributions of Liasidium variabile are reasonably well known (FeistBurkhardt 2009, Brittain et al. 2010), beyond the data provided by Riding et al. (2013) from the Copper Hill Borehole in Lincolnshire, eastern England, there are few other datasets on which to base a more comprehensive interpretation of palaeoenvironmental change. In the present study, we focus attention on the oxynotum Zone in the well-exposed shallow-marine succession at Robin Hood's Bay, Yorkshire, England; a location where there exists a well-documented ammonite biostratigraphy based on decades of careful collecting by Leslie Bairstow (Hesselbo and Jenkyns
1995, Howarth 2002, Powell 2010, Hesselbo and King 2019). Here we present an integrated palaeoenvironmental study of palynological, geochemical and mineralogical datasets to enable meaningful comparisons of the Liasidium Event with other Mesozoic and Cenozoic events.

\section{Geological setting}

The oxynotum Zone occurs within the Siliceous Shale Member of the Redcar Mudstone Formation in the Cleveland Basin, Yorkshire, UK (Fig. 1, Buckman 1915, Hesselbo and Jenkyns 1995, Howarth 2002). The Cleveland Basin was part of a network of extensional Mesozoic depocentres developed across much

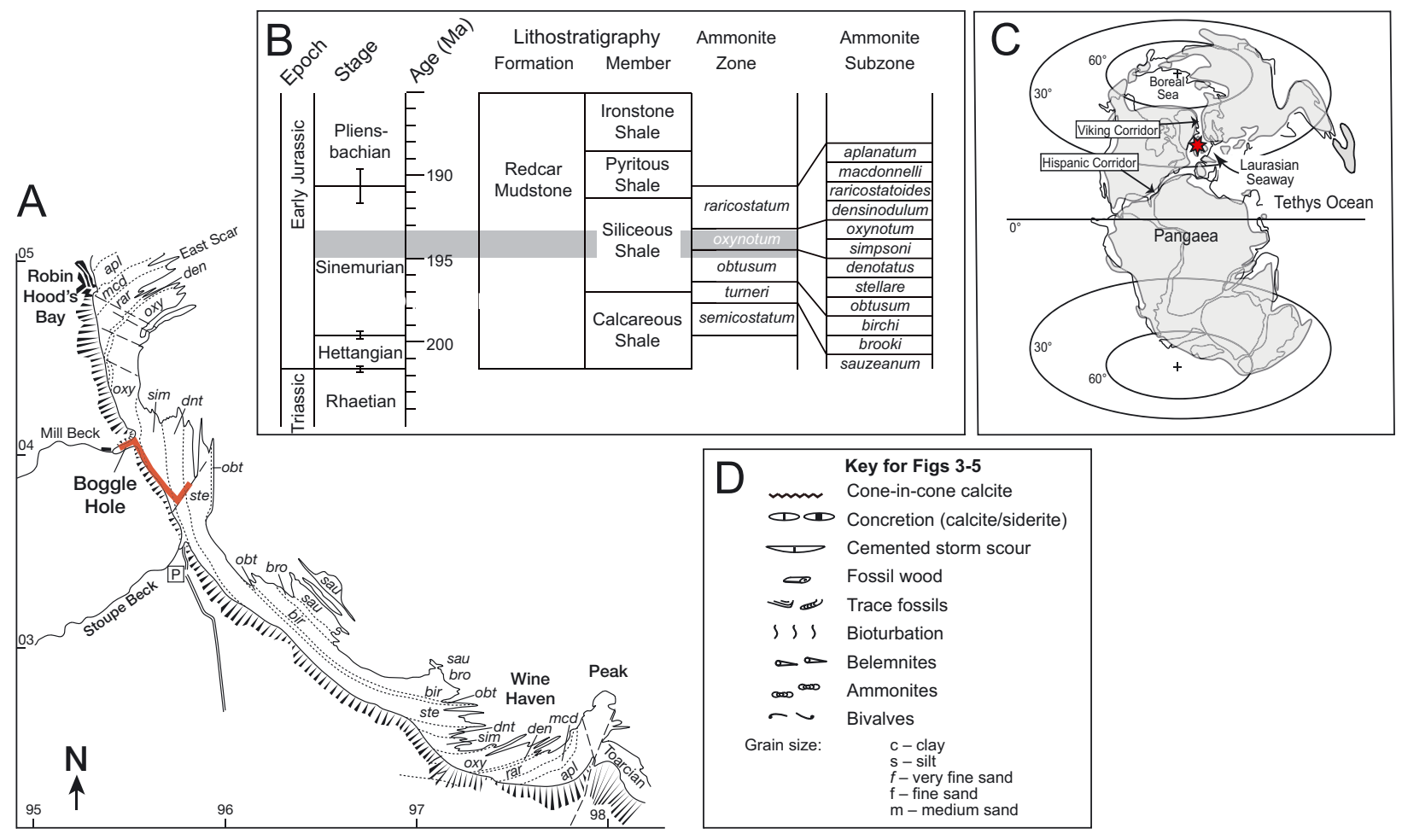

Fig. 1. A) Summary geological map of the foreshore of Robin Hood's Bay, Yorkshire, simplified from Howarth (2002). Red line shows location of section shown in Figures 2-4. Labels in italics are subzones: sau $=$ sauzeanum, bro $=$ brooki, bir $=$ birchi, obt $=$ obtusum, ste $=$ stellare, $d n t=$ denotatus, sim $=$ simpsoni, oxy $=$ oxynotum, den $=$ densinodulum, rar $=$ raricostatoides, $m c d=$ macdonnelli, apl=aplanatum. Tick marks show UK Ordnance Survey National Grid at $1 \mathrm{~km} \mathrm{spacing}$. B). Stratigraphical orientation for the Liasidium Event of Robin Hood's Bay, Yorkshire, represented by grey shading. The timescale for the Hettangian and Sinemurian stages is from Gradstein et al. (2012) and Wotzlaw et al. (2014). Lithostratigraphy and biostratigraphy from Hesselbo and Jenkyns (1995) and Howarth (2002). The placing of ammonite zones against the timescale assumes an equal duration of local ammonite subzones and is therefore approximate. C). Early Jurassic palaeogeography (modified from Dera et al. 2009). Robin Hood's Bay (the red star) is in the Cleveland Basin and occupies a mid-latitude setting within the $\sim \mathrm{N}-\mathrm{S}$ oriented Laurasian Seaway. It was likely not before the earliest Pliensbachian that the meridional Viking Corridor or latitudinal Hispanic Corridor became important conduits between the oceans. D). Key to symbols used in Figs 3-5. 


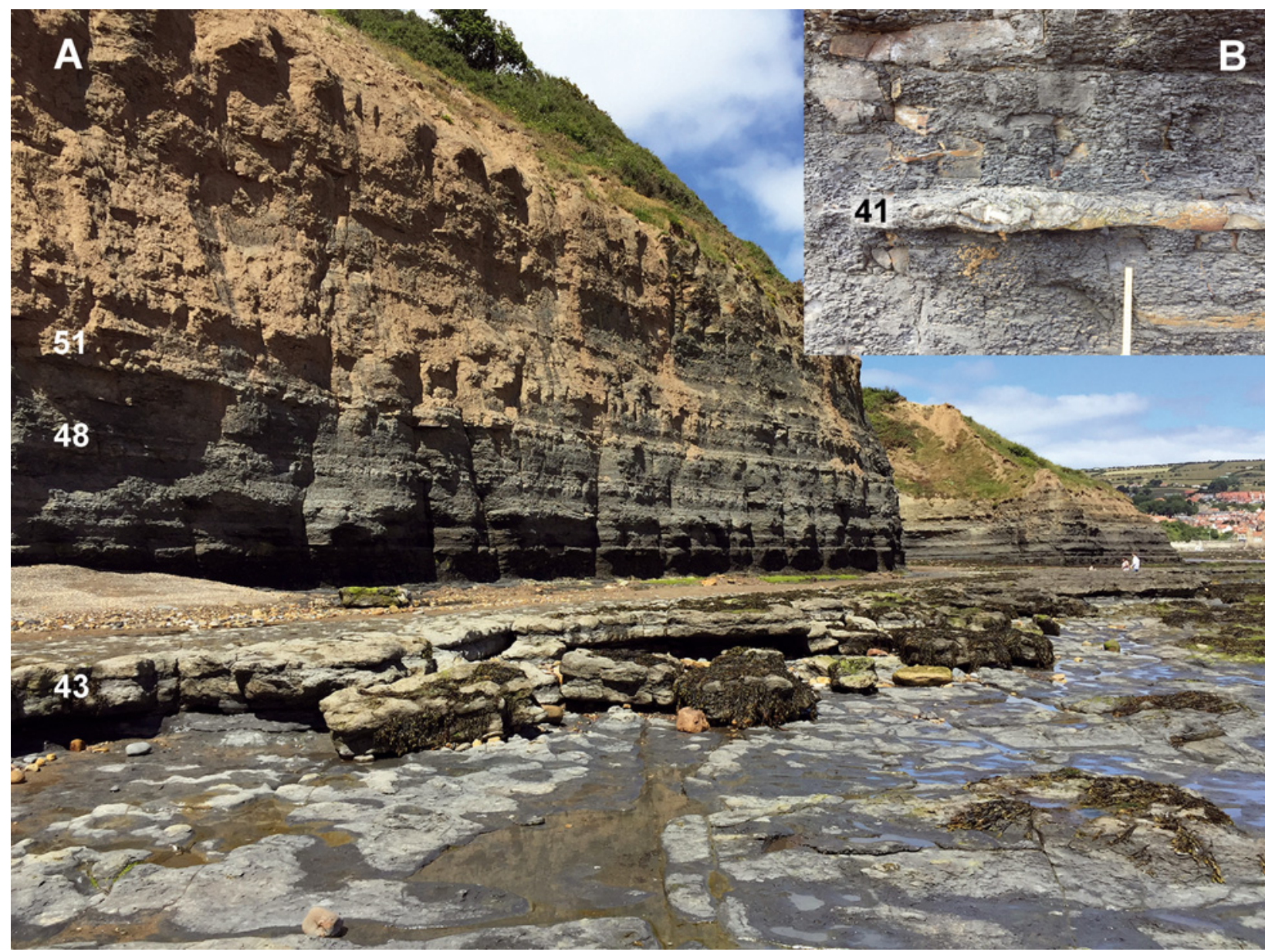

Fig. 2. A). Cliff and foreshore exposure at Robin Hood's Bay. The view is towards the NW facing Boggle Hole which is a narrow embayment in centre-right of the photograph. Key marker beds are indicated on the left side of the image. Human figures give approximate scale. B). Close up of Bed 41 in cliff immediately NW of Stoupe Beck, comprising a distinctive band of early formed concretions enveloped by later diagenetic cone-in-cone calcite. Visible scale $=20 \mathrm{~cm}$. See Figs 1 and 3 for stratigraphical and geographical reference.

of present-day northwest Europe. In the Jurassic these linked up as extensive shallow-marine basins known collectively as the Laurasian Seaway (Ziegler 1990, Cope et al. 1992, Bjerrum et al. 2001, Powell 2010). The Cleveland Basin is thought to have received sediment from Paleozoic basement rocks of the surrounding Pennine and Mid North Sea tectonic highs (Powell 2010) and, where Early Jurassic successions are exposed on the coast, the evidence points towards sediment transport from north to south (Howarth 1955, Howard 1985, Hesselbo and Jenkyns 1995). The Siliceous Shale Member comprises beds of bioturbated fossiliferous silty mudstone and well-cemented muddy sandstone, representing depositional environments that ranged from offshore transition to shoreface under storm-dominated conditions (Sellwood 1970, van Bu- chem and McCave 1989, van Buchem and Knox 1998, McIlroy 2007, Powell 2010).

\section{Methods}

\subsection{Field data}

Samples were collected at Robin Hood's Bay and correlated to previously compiled measured sections (Hesselbo and Jenkyns 1995, Howarth 2002). The lithological succession is well established, and the samples were located with reference to easily identifiable named marker beds (Figs 2-5). Heights shown in Figs 3-5 are with respect to the top of the Siliceous Shale Member and a readily recognized cemented 
sandstone, which forms a prominent ledge on the foreshore known as East Scar at Robin Hood's Bay village (Fig. 1, Hesselbo and Jenkyns 1995, Howarth 1998). This bed is well exposed at Ordnance Survey co-ordinates NZ 95500489 and NZ 9746 0232, on either side of the broad anticline that defines outcrop patterns in Robin Hood's Bay. Samples were collected on the foreshore and from the base of the cliff between Stoupe Beck and Boggle Hole (NZ 95860373 and NZ $95510408)$. The same succession is also well exposed at and around NZ 97150252.

\subsection{Palynomorph and kerogen assemblages}

Sixty samples were analysed for palynology and are from $7.03 \mathrm{~m}$ to $27.55 \mathrm{~m}$ below the top of East Scar. Samples were prepared using the standard acid digestion method (Riding and Kyffin-Hughes 2004).

\subsection{Organic matter carbon-isotopes, $\mathrm{C} / \mathrm{N}$ ratios, TOC}

For carbon isotope $\left(\delta^{13} \mathrm{C}_{\text {org }}\right)$, Total Organic Carbon (TOC), and Total Nitrogen (TN) analyses of organic matter, sample material was homogenized and powdered by hand in an agate pestle and mortar $(\sim 0.5 \mathrm{~g})$ and decarbonated in $50 \mathrm{ml}$ of $5 \%$ hydrochloric acid $(\mathrm{HCl})$, for up to 24 hours. The samples were subsequently rinsed several times with distilled water to reach neutrality. The residues were then oven-dried at $40^{\circ} \mathrm{C}$, and ground with an agate mortar. The $\delta^{13} \mathrm{C}_{\text {org }}$, TOC and TN analyses were carried out at the British Geological Survey, Nottingham, UK, by combustion in a Costech Elemental Analyser (EA) on-line to a VG TripleTrap and Optima dual-inlet mass spectrometer, with $\delta{ }^{13} \mathrm{C}_{\text {org }}$ values reported relative to V-PDB following a within-run laboratory standard calibration, with NBS-18, NBS-19 and NBS-22. Replicate analysis of well-mixed samples showed a reproducibility of $\pm<0.1 \%$ ( $1 \mathrm{SD})$. Carbon/nitrogen $(\mathrm{C} / \mathrm{N})$ were calculated from measured TOC and TN.

\subsection{X-Ray Diffraction (XRD)}

For bulk analysis by XRD a portion of sample was ground to a powder in a McCrone micronising mill. Samples were measured using a Siemens PSD X-ray diffractometer with Ni-filtered $\mathrm{CuK} \alpha$ radiation. The whole rock powder samples were scanned with $0.2 \mathrm{~mm}$ slits, and a $0.02^{\circ}$ step width from 5 to $70^{\circ}$
20. Peak deconvolution and area measurement were carried out using the application MacDiff 4.26. Semiquantitative analysis was performed using reference intensity factors derived from known mineral mixtures. Because of the strongly lithified nature of the mudstones at this locality, we use for this study only the bulk-rock XRD method and present no analyses of the separated clay-sized fraction.

\subsection{Petrography and Electron Microscopy}

Polished thin sections were examined in back-scattered electron-imaging mode, using a Zeiss EVO scanning electron microscope (SEM) equipped with an Oxford Instruments INCA energy dispersive spectral (EDS) X-ray spectrometer. EDS point analyses were obtained to characterise the detrital and authigenic mineralogy. Operating conditions were a $2 \mu \mathrm{A}$ beam current at $15 \mathrm{kV}$ accelerating voltage, and a spot diameter of approximately $2 \mu \mathrm{m}$. High-resolution images were obtained with a FEI QUANTA 650.

\subsection{Hand-Held X-Ray Fluorescence (HH-XRF)}

Samples for HH-XRF analysis were sub-sampled splits of powders also used for $\delta^{13} \mathrm{C}$ and $\mathrm{C} / \mathrm{N}$ ratios of organic matter, TOC, and XRD. Powders were transferred into $30 \mathrm{ml}$ plastic beakers such that a layer of at least $1 \mathrm{~cm}$ thickness was formed, and the beakers were then covered with PVC film of approximately $10 \mu \mathrm{m}$ thickness. The beakers were inverted onto the detector window of the HH-XRF such that the sample powder made a continuous surface on the PVC film, minimizing porosity-related and absorption-related biases of the readings.

Analysis was conducted using an Olympus Innov-X Delta Premium XRF Analyzer HH-XRF at the University of Exeter, Camborne School of Mines, set in Geochem mode. Readings were collected for $120 \mathrm{~s}$ each for excitation voltages of $40 \mathrm{kV}$ and $10 \mathrm{kV}$, capturing the trace and major element concentrations. Reproducibility of the measurements was controlled through interspersed measurements of the standard NIST 2710a; see Supplementary Data. Due to matrix and instrumental effects, HH-XRF results can only be regarded as a semi-quantitative, and the accuracy of the signal is unknown; nevertheless, relative trends in the readings are thought to be robust as evidenced by standard reproducibility and matching results of XRD analyses. 


\section{Results}

\subsection{Bulk organic matter carbon isotopes, TOC, $\mathrm{C} / \mathrm{N}$ ratios}

Carbon-isotope ratios from bulk organic matter show clear stratigraphical trends through the obtusum and oxynotum zones at Robin Hood's Bay (Fig. 3). Broadly, $\delta^{13} \mathrm{C}_{\text {org }}$ values are relatively low at the base of the obtusum Zone ( $\sim-25.5 \%$ ), and become gradually less negative upwards into the oxynotum Zone $(\sim-24.5 \%)$. The middle oxynotum Zone is characterised by two distinct negative excursions, each reaching $<-26 \%$, the lower occurring within the simpsoni Subzone, and the upper at the boundary between the simpsoni Subzone and the oxynotum Subzone. The upper oxynotum Subzone exhibits carbon-isotope values distinctly less negative, with $\delta^{13} \mathrm{C}_{\text {org }}$ in the range -24.5 to $-24.0 \%$ (Fig. 3). The new data from Robin Hood's Bay are at a much higher resolution than previously reported $\delta^{13} \mathrm{C}_{\text {carb }}$ from macrofossil carbonate (Korte and Hesselbo 2011), and also show evidence of bed-scale fluctuations in the order of $0.5-1.0 \%$. A single outlying value of $-22.40 \%$ occurs in the Double Band sandstone, at $-15.71 \mathrm{~m}$ (Fig. 3), which we attribute to the possible incomplete dissolution of refractory carbonate grains such as ferroan dolomite.

Total organic carbon (TOC) contents are generally low, with the overwhelming majority of measurements lying between 0.2 and $1 \%$. The lower half of the section analysed exhibits relatively uniform values $\sim 0.5 \%$, whilst in the upper half, larger fluctuations are observed with lowest TOC values in sandstone beds and higher values in intervening mudstone beds, with an overall upward trend to higher TOC values in the top $\sim 5 \mathrm{~m}$.

Carbon/nitrogen $(\mathrm{C} / \mathrm{N})$ ratios for the bulk organic matter analysed also show clear simple stratigraphical trends (Fig. 3). Ratios are generally $\sim 7-10$ in the bottom half of the succession analysed up to the simpsoni-oxynotum subzonal boundary stratigraphically, rising abruptly to $\sim 10-15$ in the upper part of the oxynotum Zone. The $\mathrm{C} / \mathrm{N}$ ratios likely reflect relative proportions of marine and terrestrial organic matter components, with Jurassic organic matter of marine origin being relatively depleted in carbon (e. g., Tyson et al. 1995, Hedges et al. 1997). In the Robin Hood's Bay succession, the overall trends in $\mathrm{C} / \mathrm{N}$ are crudely parallel to those of grain size, reflecting the higher relative concentrations of terrestrial organic matter in depositional environments that lay closer to the palaeoshoreline.

\subsection{Palynology and palynostratigraphy}

The palynological data obtained are fully documented in Supplementary Fig. 2 and the Supplementary Data File, and selected specimens are illustrated in Fig. 6. The palynomorph species recognised herein are also listed, with their full author citations, in Appendix 1. All the samples, except PB 239 ( $-24.05 \mathrm{~m}$ in Fig. 3) which proved relatively sparse, yielded abundant and well- to moderately well-preserved palynofloras; the taxonomic diversity is relatively low throughout.

The assemblages are consistently dominated by gymnospermous pollen grains, particularly bisaccate forms and Perinopollenites elatoides. Furthermore, Cerebropollenites macroverrucosus, Chasmatosporites spp. and Classopollis classoides were recorded throughout in lower proportions. The acme of the thermophilic species Classopollis classoides is in samples PB 117 and PB 15 (-18.55 m and $-18.35 \mathrm{~m}$ in Fig. 3). Araucariacites australis, Cycadopites spp. and Vitreisporites pallidus are present sporadically and in low numbers.

Pteridophyte spores are markedly subordinate to gymnospermous pollen grains; the former are dominated by simple, smooth forms which are assigned to the genus Cyathidites (largely Cyathidites australis and Cyathidites minor). Other spores encountered include Baculatisporites/Osmundacidites spp., Concavisporites spp., Contignisporites spp., Coronatispora valdensis, Dictyophyllidites spp., indeterminate forms, Ischyosporites spp., Kraeuselisporites reissingeri, Retitriletes austroclavatidites, Retitriletes spp. and Zebrasporites interscriptus (Supplementary Fig. 2 and Supplementary Data File). The pollen and spores are characteristic of the Lower Jurassic of Europe and surrounding regions (e. g. Srivastava 1987, Srivastava 2011, Weiss 1989).

Aquatic palynomorphs are present throughout in substantially lower proportions than the terrestriallyderived taxa. All are marine, except the freshwater/ brackish alga Botryococcus braunii which is present sporadically. This occurrence of marine microplankton, like the presence throughout of marine macrofauna, is consistent with deposition in a shelfal setting (Coward et al. 2003). The majority of the marine palynomorphs are acanthomorph acritarchs (Micrhystridium spp.). Other marine indices are the acritarch genus Veryhachium and prasinophytes (Tasmanites spp). The only 


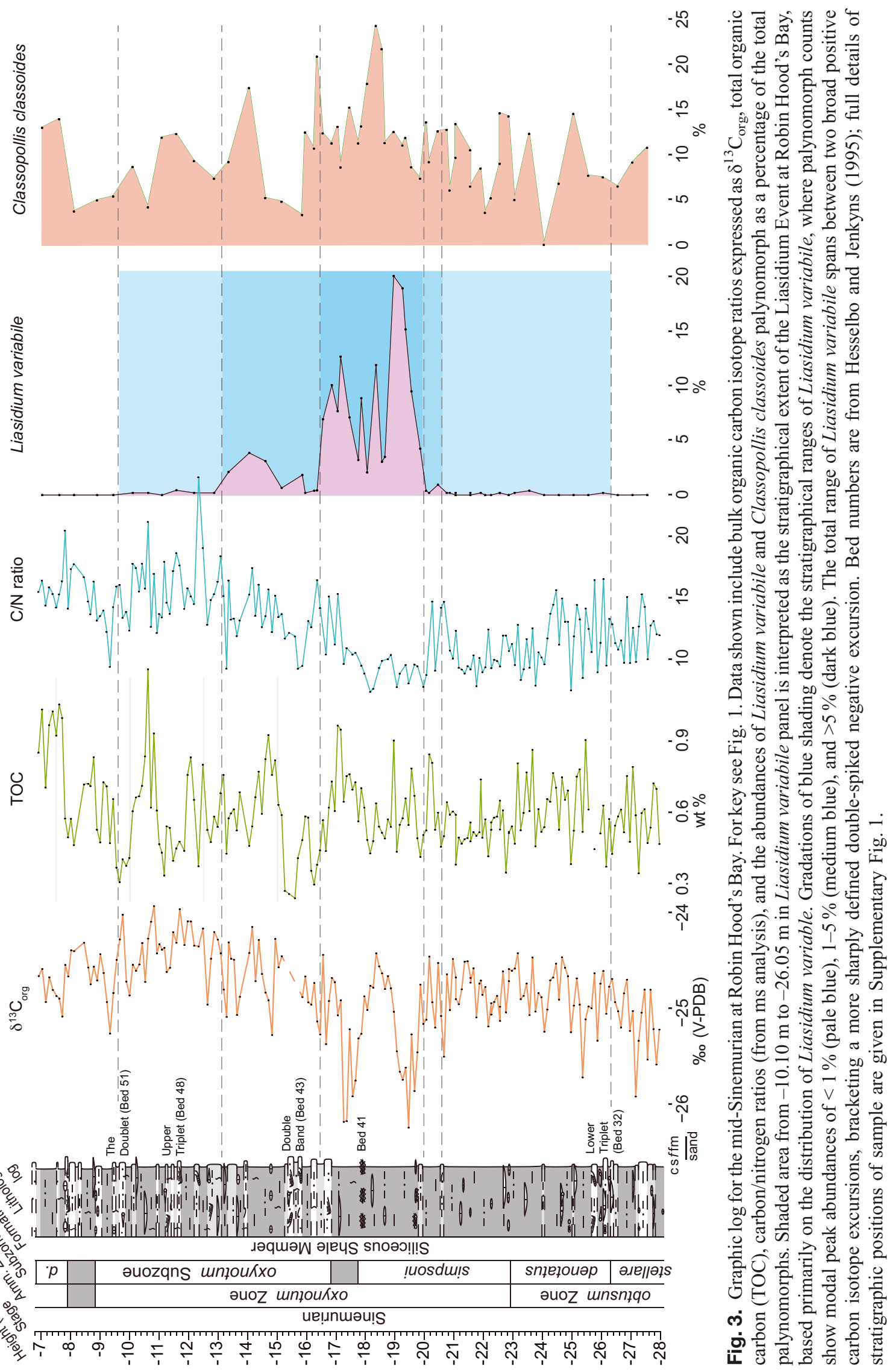



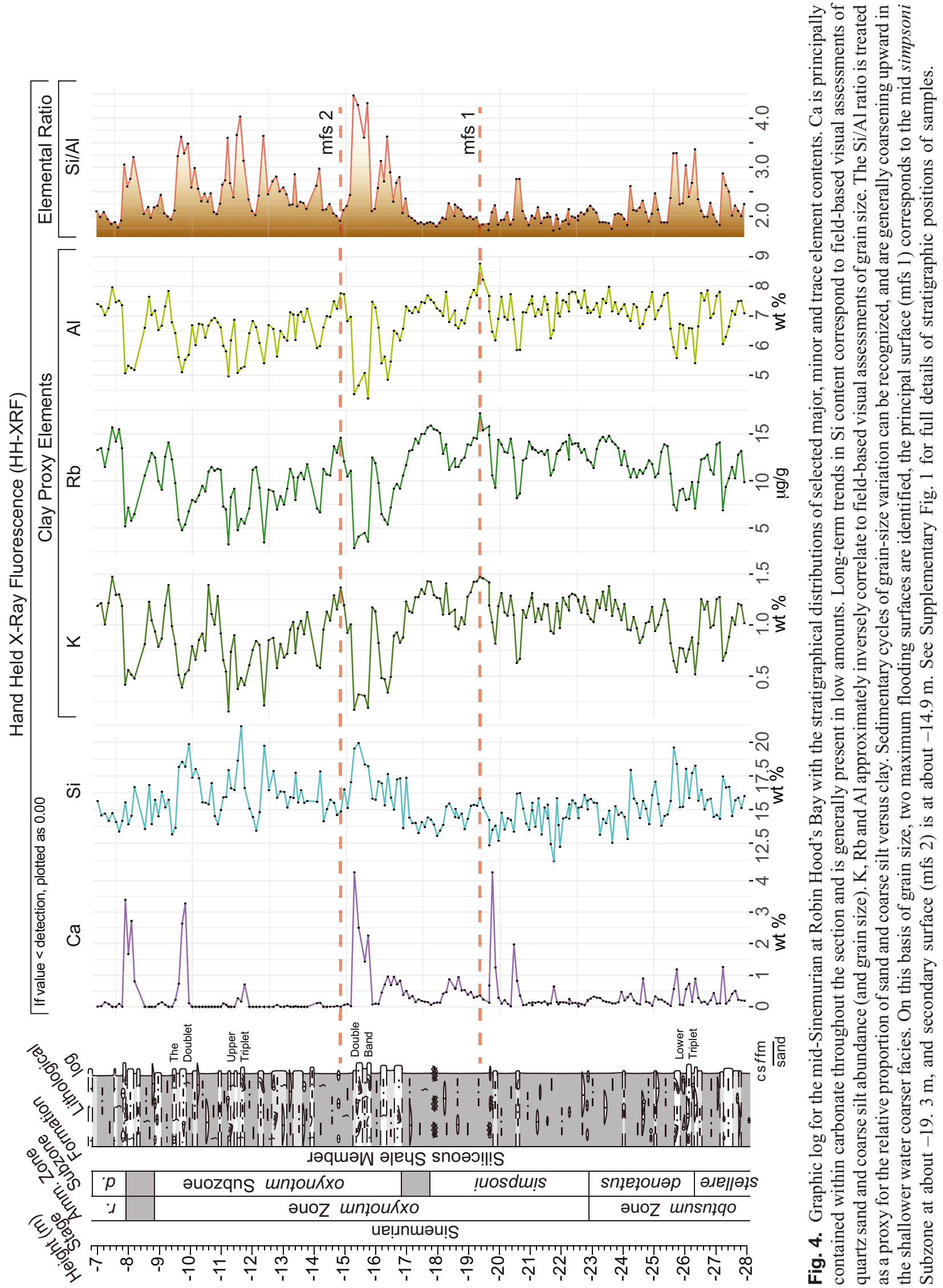
authochthonous dinoflagellate cyst species recognised was Liasidium variabile between samples PB 219 at $-26.05 \mathrm{~m}$ and PB 74 at $-10.10 \mathrm{~m}$ (see below). The acme of this species is in samples PB 122 and PB $12(-19.35$ to $-19.25 \mathrm{~m}$ ). Foraminiferal test linings proved sparse; this strongly suggests that benthic foraminifers were relatively rare throughout the succession studied (Supplementary Fig. 2 and Supplementary Data File).

Reworked palynomorphs were encountered consistently. These allochthonous forms are dominated by Carboniferous spores, largely Densosporites spp. and Lycospora pusilla. The latter forms are stratigraphically long-ranging, but Diatomozonotriletes sp. and Tripartites spp. strongly suggest a Mississippian source, and Calamospora spp. and Reinschospora sp. are indicative of input from the Pennsylvanian (Smith and Butterworth 1967, Clayton et al. 1977). This spectrum of reworked Mississippian and Pennsylvanian spores is typical of the post-Paleozoic of eastern England (Lee et al. 2002, Riding et al. 2003, Busfield et al. 2015). The Carboniferous input to the Cleveland Basin is interpreted as fluvial from the surrounding Mississippian and Pennsylvanian strata, especially to the north and the west. Recycled Permian and Triassic palynomorphs were observed in samples SB $3(-22.25 \mathrm{~m})$, PB $7(-20.75 \mathrm{~m})$ and PB 64 $(-11.09 \mathrm{~m})$ (Supplementary Data File).

The percentages of the four main kerogen macerals are given in the Supplementary Data File. The organic residues are generally dominated by wood fragments and palynomorphs. Other plant tissues and amorphous organic material are both consistently subordinate. Supplementary Fig. 2 demonstrates no major perturbations or trends in the abundances of the principal kerogen types.

The stratigraphical distributions and abundances of two key palynomorphs, the dinoflagellate cyst Liasidium variabile and the pollen grain Classopollis classoides are presented in Fig. 3. The dinoflagellate cyst Liasidium variabile was established by Drugg (1978, p. 69-70) from the oxynotum Zone of the Swabian Jura, near Balingen, Baden-Württemberg, southwest Germany. The samples studied by Drugg (1978) are all from the lowermost three metres of the oxynotum Zone of Balingen, presumably within the simpsoni Subzone. Drugg (1978, p. 70) also mentioned that Liasidium variabile is abundant in the oxynotum Zone of Robin Hood's Bay. Bucefalo Palliani and Riding (2000, fig. 4) reported Liasidium variabile from the turneri and oxynotum zones of Robin Hood's Bay. The occurrence of this species in the turneri Zone appears to be anomalous (Brittain et al. 2010, fig. 5), and the ammonite zonal attribution of the single sample MPA 8044 of Bucefalo Palliani and Riding (2000) may be unreliable or the data otherwise erroneous. The biostratigraphy, mode of nutrition, morphology, palaeobiology, phylogeny and suprageneric classification of Liasidium variabile was discussed by Feist-Burkhardt (2009) and Brittain et al. (2010). A cartoon of this species was used in the logo of the Fifth International Conference on Modern and Fossil Dinoflagellates, Zeist, The Netherlands, 1993 (Head and Harland 2013, fig. 7).

The data herein represents, by a considerable margin, the most detailed stratigraphical record of Liasidium variabile to date; all 60 samples are confidently correlated to the ammonite zonation (Fig. 3). The total range of Liasidium variabile at Robin Hood's Bay is from the base of the denotatus Subzone of the obtusum Zone to close to the top of the oxynotum Subzone of the oxynotum Zone (samples PB219, $-26.05 \mathrm{~m}$, to PB74, $-10.10 \mathrm{~m}$, Fig. 3). However, the species is only consistent and common ( $>5 \%)$ in the oxynotum Zone, from the middle of the simpsoni Subzone to the base of the oxynotum Subzone (samples PB10, $-19.85 \mathrm{~m}$ to PB21, -16.55 m, Fig. 3). There are three samples with relatively common Liasidium variabile stratigraphically above this, in the middle part of the oxynotum Subzone (samples PB34, $-14.60 \mathrm{~m}$ to PB44, -13.35 , Fig. 3). By contrast, Liasidium variabile is sparse and sporadic throughout the lowermost and uppermost parts of the range of this species. This definitive stratigraphical distribution of Liasidium variabile from the denotatus to oxynotum ammonite subzones is entirely consistent with the records from the Nettleton Bottom and Brown Moor boreholes in eastern England (Riding 1987, fig. 3; Bucefalo Palliani and Riding 2000, fig. 3).

\subsection{Elemental geochemistry}

Full elemental abundances are provided in the Supplementary Data File. The calcium content is generally low, typically $<1 \%$, with notable spikes of up to $\sim 4 \%$ at some, but not all, cemented sandstone and siltstone beds (Fig. 4). Low $\mathrm{Ca}$ is consistent with low calcite content of the Siliceous Shale Member as discussed in section 4.4 below. The silicon readings range between 10-20\% (certainly an underestimate of the true Si content), with reducing relative Si content upwards to the middle oxynotum Zone, and variable but generally greater values in the upper oxynotum Zone. These 


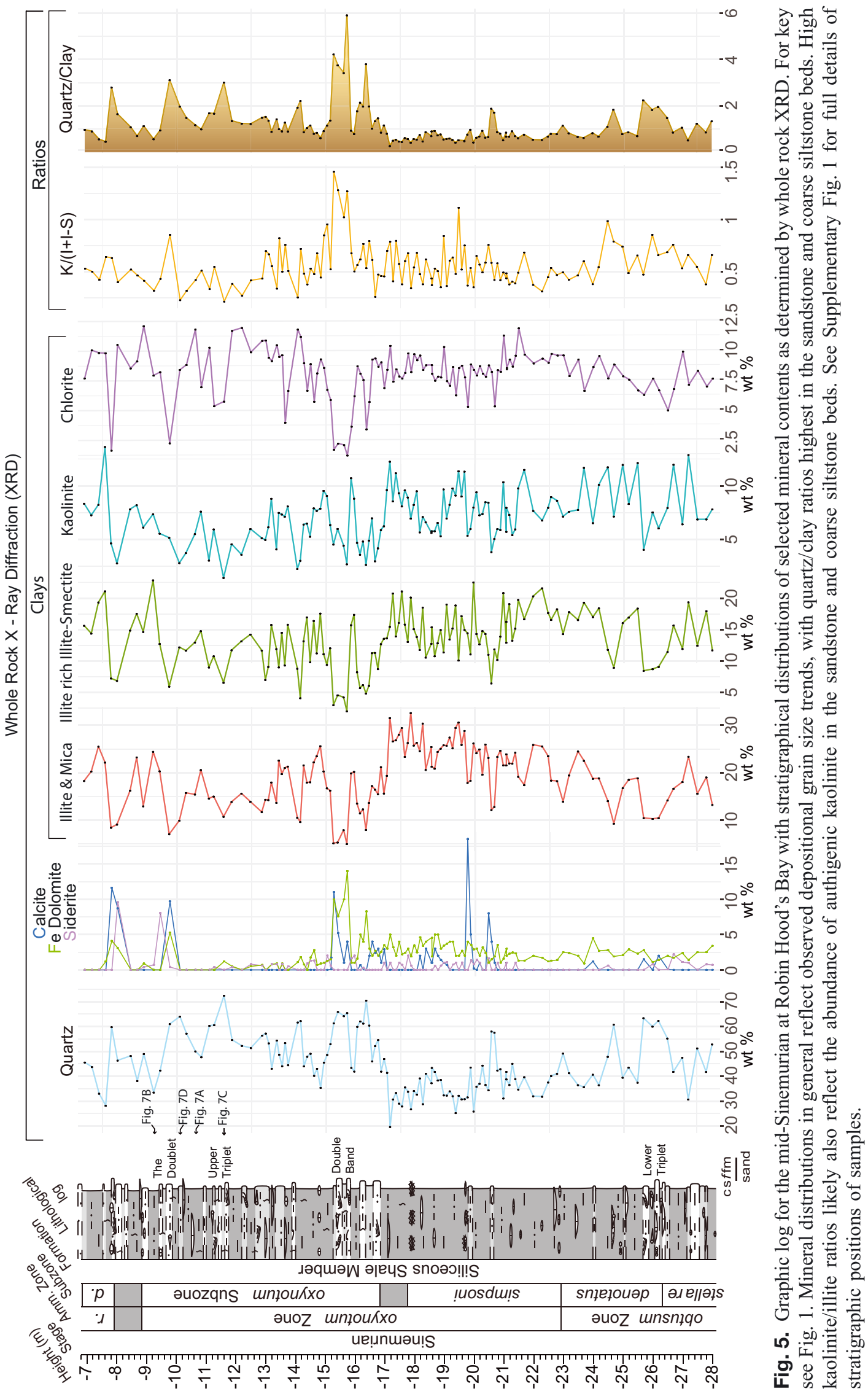


trends (Fig. 3) are visually correlated with the described sandy and silty beds and likely reflect the quartz sand and silt contents. Potassium, rubidium and aluminium exhibit broadly very similar stratigraphical distributions to each other, specifically increasing trends up to the middle oxynotum Zone, and variable but generally lower values in the upper oxynotum Zone. These elements all have in common an affinity with clay minerals and feldspars (e.g. Calvert and Pedersen 2007). Given the inverse correlation between $\mathrm{K}, \mathrm{Rb}, \mathrm{Al}$ and $\mathrm{Si}$ (Fig. 4), it is likely that the principal host phases are clay minerals. The $\mathrm{Si} / \mathrm{Al}$ ratio therefore provides a reliable indication of quartz versus clay content and grain size, and an excellent visual correlation is observed with the sandy and silty beds shown in Fig. 4. All these elemental records highlight the increasingly fine-grained characteristics of the sediment up to the mid oxynotum Zone, and the generally coarser nature of the strata above. Also noteworthy is the clear development of coarsening-upward (i. e. shallowingupward) stratal packages in the order of $\sim 2 \mathrm{~m}$ thickness, discussed further in section 5.3 below. There is a lack of enrichment in redox-sensitive metals throughout (Supplementary Data File).

\subsection{Detrital and authigenic mineralogy}

Full mineral abundance data are provided in the Supplementary Data File. Mineralogical trends have been highlighted by plotting XRD data from powdered whole rock against stratigraphical height (Fig. 5). Quartz abundance and the quartz/clay ratio may both be used as proxies for grain-size in clastic sediments. Plotted against height, both proxies show excellent correlation with the visual description of grain-size (Fig. 5) and differ only in minor respects compared to quartz/clay ratios inferred from elemental data (Fig. 4).

Carbonate content can be subdivided into calcite, ferroan dolomite and siderite components, with peak abundances for all these carbonate phases occurring in the sandstone beds. Carbonate concretions were avoided during field sampling and hence are not recorded in the mineralogical data of Fig. 5 (and likewise for the carbon-isotope data of Fig. 3). Background carbonate contents of these rocks is very low (mostly $<5 \%$ ).

The kaolinite to illite+illite-smectite (K/I+IS) ratio for the XRD data from powdered whole rock shows a fair correlation with grain-size, with more kaolinite present in the coarser beds: peaks in kaolinite abundance $(\mathrm{K} / \mathrm{I}+\mathrm{IS})$ are associated with each of the named
Fig. 6. Selected palynomorphs from the Siliceous Shale Member of Robin Hood's Bay, North Yorkshire (Copyright British Geological Survey (C) UKRI 2019). A to C are in situ dinoflagellate cysts, D and $\mathrm{E}$ are in situ gymnosperm pollen grains, and $\mathrm{F}$ to $\mathrm{J}$ are reworked Carboniferous spores. The images were all taken using Differential Interference Contrast (DIC). The specimens are housed in the MPK micropalaeontological type and figured collection of the British Geological Survey, Keyworth, Nottingham NG12 5GG, UK. A. Liasidium variabile Drugg 1978. Sample PB 269 $(-21.05 \mathrm{~m})$. Specimen MPK 14650. Overall length: $53.5 \mu \mathrm{m}$; maximum width: $40 \mu \mathrm{m}$. Note the biconical outline and the very faint longitudinal striations. The latter are reminiscent of the Late Cretaceous to Miocene peridinacean genus Phelodinium (e. g. Bujak and Davies 1993, pl. 9, figs. 18-20). B. Liasidium variabile Drugg 1978. Sample PB 117 $(-18.55 \mathrm{~m})$. Specimen MPK 14651. Overall length: $51 \mu \mathrm{m}$; maximum width: $38 \mu \mathrm{m}$.C. Liasidium variabile Drugg 1978. Sample PB 20 (-16.85 m). Specimen MPK 14652. Overall length: $45 \mu \mathrm{m}$; maximum width: $38 \mu \mathrm{m}$. Note the relatively large apical horn and the prominent cingulum. D. Perinopollenites elatoides Couper 1958. Sample PB 224 $(-25.55 \mathrm{~m})$. Specimen MPK 14653. Dimensions: $40 \mathrm{x}$ $35.5 \mu \mathrm{m}$. E. A tetrad of Classopollis classoides (Pflug 1953) Pocock \& Jansonius 1961. Sample PB $13(-18.95 \mathrm{~m})$. Specimen MPK 14654. Dimensions: 42 x $38 \mu \mathrm{m}$. F. Lycospora pusilla (Ibrahim 1932) Schopf et al. 1944. Sample PB $74(-10.10 \mathrm{~m})$. Specimen MPK 14655. Dimensions: $24.5 \mathrm{x}$ $23 \mu \mathrm{m}$. G. Densosporites sp. Sample PB $254(-22.55 \mathrm{~m})$. Specimen MPK 14656. Dimensions: 31 x $29 \mu \mathrm{m}$. H. Densosporites sp. Sample PB 127 (-20.05 m). Specimen MPK 14657. Dimensions: 35.5 x $24.5 \mu \mathrm{m}$. I. Tripartites trilinguis (Horst 1943) Potonié \& Kremp 1955. Sample PB 19 $(-17.15 \mathrm{~m})$. Specimen MPK 14658. Dimensions: $40 \mathrm{x}$ $38 \mu \mathrm{m}$. J. Tripartites vetustus Schemel 1950. Sample PB 17 (-17.75 m). Specimen MPK 14659. Dimensions: $42 \mathrm{x}$ $40 \mu \mathrm{m}$.

sandstone beds in Fig. 5, but other minor peaks also occur where there is no prominent sandstone bed. The kaolinite abundance peak associated with the Double Band coincides with low TOC values, and small amounts of barite cement.

\subsection{Petrography}

Samples were selected for petrography to cover the range of lithological types which were observed, together with lows and highs in kaolinite abundance, as determined from XRD data. All lithologies are bioturbated to varying degrees, and no primary lamination is observed in any samples studied using the SEM. Where bioturbation has mixed sand-rich or silt- 

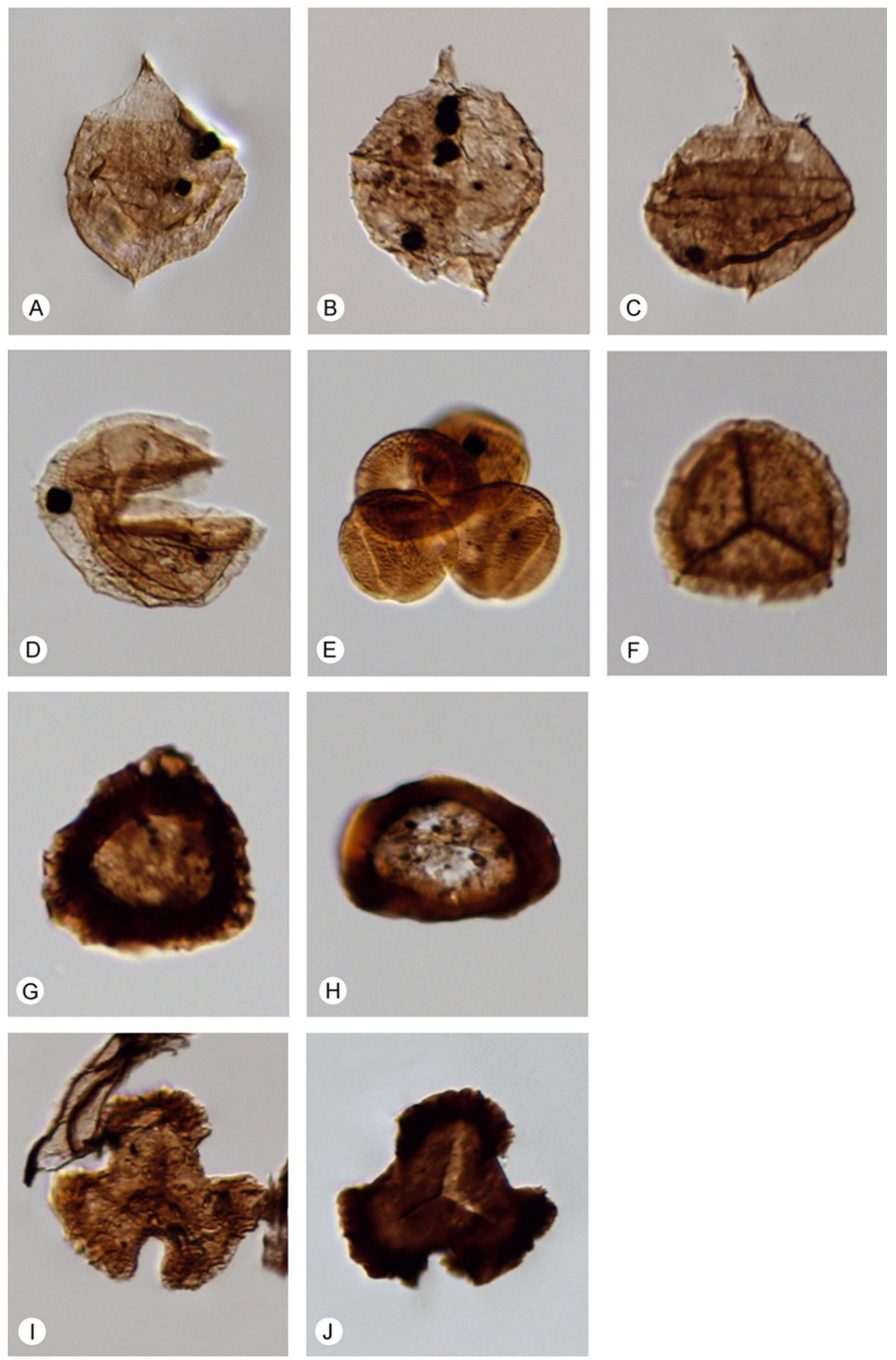

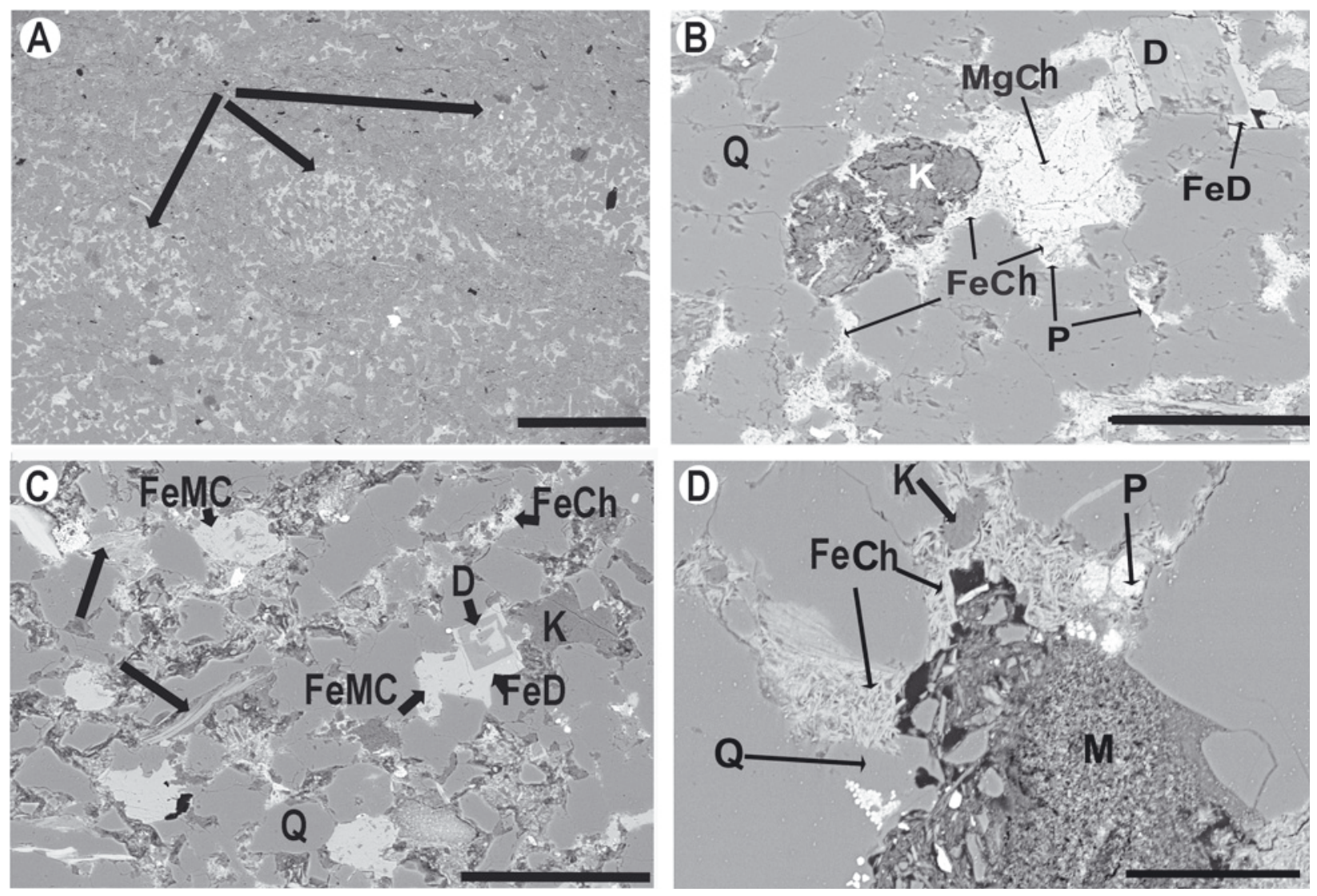

Fig. 7. SEM images demonstrating the main paragenetic relationships. For the stratigraphical positions of the samples illustrated see Fig. 4. A. Arrows indicate pods of sediment that are dominated by quartz sand (dark grey) and chlorite (pale grey), and enclosed in finer grained clay-rich sediment (dark grey). Scale bar $=500 \mu \mathrm{m}$. Sample PB39, $-10.62 \mathrm{~m}$. B. Detrital mica has been replaced by a sand-size aggregate of kaolinite $(\mathrm{K})$. Detrital $\mathrm{Mg}$ chlorite $(\mathrm{MgCh})$ has been partially replaced by Fe chlorite (FeCh). The Fe chlorite has overgrown authigenic kaolinite and pyrite (P), and filled primary pore space. Dolomite (D) has been overgrown by Fe dolomite $(\mathrm{FeD}) . \mathrm{Q}=$ quartz, the elongate quartz grain boundaries indicate either pressure solution or overgrowths. Scale bar $=100 \mu \mathrm{m}$. Sample PB64 $-9.22 \mathrm{~m}$. C. Very fine sand with minor anhedral FeMg calcite $($ FeMC) and euhedral dolomite $(\mathrm{D})$ with ferroan overgrowths $(\mathrm{FeD}) . \mathrm{K}=$ kaolinite that has replaced mica, $\mathrm{Q}=\mathrm{quartz}, \mathrm{FeCh}=$ Fe chlorite. Scale bar $=200 \mu \mathrm{m}$. Sample PB102, $-11.58 \mathrm{~m}$. D. Pyrite framboids (P) and authigenic kaolinite after mica (K) overgrown by authigenic Fe chlorite (FeCh). Quartz overgrowth cement (Q) is intergrown with chlorite and pyrite. $\mathrm{M}=$ detrital clay matrix. Scale bar $=20 \mu \mathrm{m}$. Sample PB49, $-10.10 \mathrm{~m}$.

rich sediment with clay-rich sediment, distinct areas retaining a fine or coarse texture are observed (arrowed in Fig. 7A, Sample PB39, $-10.62 \mathrm{~m}$ ). The mineral assemblage is dominated by quartz and phyllosilicates, together with small amounts (a few $\%$ at most) of feldspar, carbonate minerals and pyrite (Fig. 7B, Sample PB64, $-9.22 \mathrm{~m}$ ). Clay minerals are mainly illite and illite-rich illite-smectite, with slightly smaller proportions of kaolinite and chlorite. These findings are consistent with the broad description of a "kaolinmica" assemblage reported by Jeans (2006) for the Sinemurian of the Cleveland Basin.

From back-scattered electron microscopy (BSEM) it is evident that the silt and sand fraction is dominated by quartz, with subordinate muscovite and Mg-chlorite, rare feldspars, calcite bioclasts, Ti-oxide and apatite (Fig. 7C, Sample PB102, $-11.58 \mathrm{~m}$ ). The clay matrix has the mid-grey atomic number contrast consistent with it being predominantly illite and illitesmectite. Authigenic kaolinite occurs mainly within areas of coarser sediment, occurring as silt and sandsize aggregates that have replaced muscovite grains, remnants of which may be observed within the kaolinite grains (Fig. 7C, D; PB102, $-11.58 \mathrm{~m}$; PB49, $-10.10 \mathrm{~m})$. Detrital, clay-grade kaolinite may also be present in the mainly illitic matrix. Authigenic Fe-chlorite, comprising platelets with face-to-edge texture, occur and these occlude porosity in the sand- 
stone beds (Fig. 7D) and, to a lesser extent, in the siltrich mudstone. $\mathrm{Mg}$-chlorite appears to be the parent mineral for the authigenic Fe-chlorite (Fig. 7C). Where contacts are observed, the chlorite has overgrown authigenic kaolinite and ferroan dolomite (Figs. 7B-D). Sparse quartz cement in the sandstone beds has overgrown the authigenic chlorite (Figure 7D). Authigenic quartz has also partially replaced macrofossils.

Authigenic carbonate grains are rare in the samples analysed, and occur chiefly as siderite or dolomite. Siderite has overgrown pyrite but textural relationships with other cements were not observed. Occasional anhedral calcite or euhedral dolomite grains are also present, and both typically have Fe-rich overgrowths. The relationship of calcite to ferroan dolomite was not observed. Where quartz overgrowth, dolomite, and ferroan dolomite occur together, the ferroan dolomite has overgrown the quartz cement, but the non-ferroan dolomite cement has not, and abuts detrital quartz directly (Fig. 7C). Calcite has also overgrown pyrite and kaolinite. Pyrite framboids are common, and occur mainly as elongate aggregates that may have replaced fossil wood. Pyrite framboids are also found infilling microfossils and in clay matrix. Smaller amounts of euhedral pyrite occur throughout. Trace amounts of diagenetic barite occur, particularly in sandstone beds, where it has replaced calcite.

\section{Discussion}

This investigation supports the concept of a Liasidium Event outlined by Riding et al. (2013) but also provides substantially more detail.

\subsection{Carbon isotope stratigraphy}

At Robin Hood's Bay, the 'double spike' CIE from bulk organic matter reported here occurs in the lower oxynotum Zone and is similar, if somewhat smaller, in magnitude (1.5\% vs $2.5 \%$ o) to the already described but poorly resolved excursion from palynological residues and bulk organic matter from the Copper Hill Borehole (Riding et al. 2013); we interpret these excursions as correlative stratigraphical features (Fig. 8). The difference in characteristics between these localities may be due to different make-up of the organic matter content, poorer sample resolution in Riding et al. (2013), and missing strata at the base of the oxynotum Zone in the Copper Hill Borehole where a significant hiatus has already been inferred from reworked concretions.

There are very few other carbon-isotope records generated for the mid- to late Sinemurian interval, either using bulk organic matter (Katz et al. 2005, Jenkyns and Weedon 2013, Porter et al. 2014, Peti et al. 2017, van de Schootbrugge et al. 2019), bulk carbonate (Duarte et al. 2014, Franceschi et al. 2014, Masetti et al. 2016), or more discriminated materials such as shell (Korte and Hesselbo 2011). Additionally, with the exception of Porter et al. (2014), records are centered on Europe. Available literature on European successions fails to resolve the obtusum/oxynotum zone carbon-isotope record confidently due to missing strata (Jenkyns and Weedon 2013), low stratigraphical resolution (Hamon and Merzeraud 2007, Korte and Hesselbo 2011, Duarte et al. 2014, Franceschi et al. 2014, Peti et al. 2017), or uncertain biostratigraphical control (Masetti et al. 2016, Peti et al. 2017). A single relatively light isotope value from bulk organic matter has been previously reported from the Llanbedr (Mochras Farm) Borehole in North Wales, Cardigan Bay Basin (Katz et al. 2005), but interpretation of the oxynotum Zone at that location is made more problematical by low sample resolution, and the occurrence of what is interpreted to be a significant fault (Woodland 1971). The Robin Hood's Bay outcrop therefore currently represents the principal carbon isotope record for the Liasidium Event, but at present there is no definitive evidence for geographical extent.

\subsection{Palynological evidence for marine and terrestrial environmental change}

As was the case in the Copper Hill Borehole (Riding et al. 2013), there is a close co-incidence between the negative carbon-isotope excursion, the acme of the dinoflagellate cyst Liasidium variabile, and the abundance of the pollen grain Classopollis classoides. It is noteworthy, however, that there is not a simple one-toone relationship between the abundance peaks of these two taxa (Fig. 3), with maximum concentrations of Classopollis classoides occurring in the stratigraphical interval between spikes in the occurrences of Liasidium variabile. This stratigraphical distribution may reflect differences in timing of climatic changes in the terrestrial versus marine environments. The lack of relationship between abundances of either of these two taxa and $\mathrm{C} / \mathrm{N}$ ratios of the bulk organic matter (Fig. 3) argues against a taphonomic control related to distance 


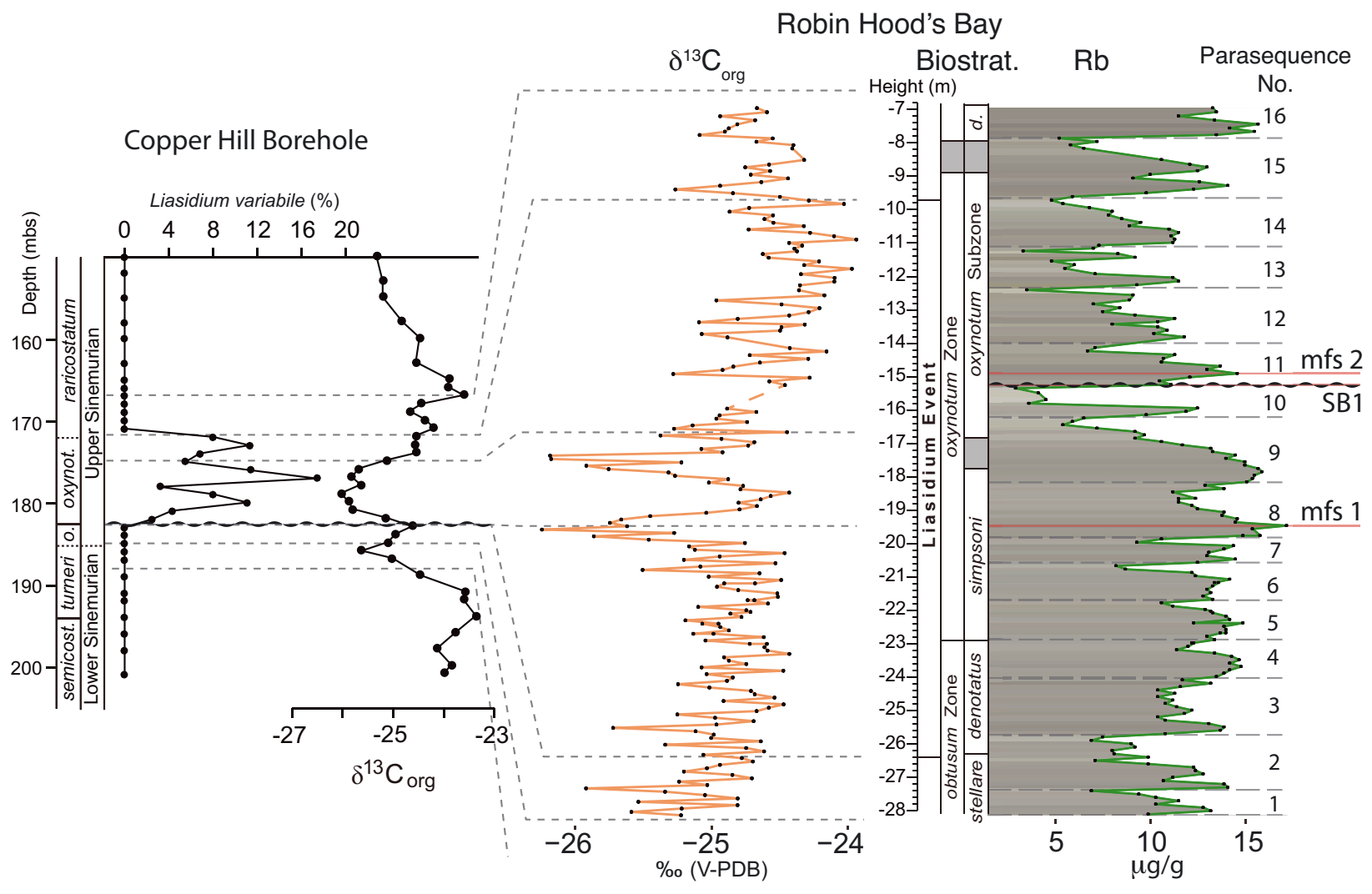

Fig. 8. Correlation between the Copper Hill Borehole, Lincolnshire (Riding et al. 2013), and Robin Hood's Bay (this study). Correlation based on carbon-isotope stratigraphy and range of Liasidium variabile is shown by grey dashed lines. Sequence stratigraphic interpretation is shown overlain on $\mathrm{Rb}$ content (as a clay proxy) from HH-XRF; shades of grey are from colour scans of the dry powder on which HH-XRF measurements were made. Parasequences 1 and 2 are aggradational, 3-7 backstepping, 8-10 forestepping, 11-13 forestepping, and 14-16 backstepping. A significant hiatus and sequence boundary is inferred at Robin Hood's Bay between parasequences 10 and $11(-15.25 \mathrm{~m})$. Maximum flooding surfaces are interpreted at $-19.45 \mathrm{~m}$ and $-14.92 \mathrm{~m}$. The succession at Copper Hill is previously known to be incomplete based on the occurrence of a hiatus concretion level at $182 \mathrm{~m}$ depth.

from shoreline and mix of terrestrial versus marine palynomorphs (cf. also Supplementary Fig. 2).

Classopollis classoides and Liasidium variabile are the only numerically significant palynomorphs that exhibit noteworthy changes. Bisaccate pollen and Perinopollenites elatoides appear to have an inverse relationship to each other, but do not exhibit significant fluctuations over the Liasidium Event. Similarly, the levels of amorphous organic matter and wood/plant tissue, and the continental/marine palynomorph ratio, do not vary substantially, although there is a distinct spike of amorphous organic material coincident with the lower acme of Liasidium variabile in the simpsoni Subzone (Supplementary Fig. 2).

The most abundant palynomorph throughout is the gymnosperm pollen species Perinopollenites elatoides (Supplementary Fig. 2, Supplementary Data File). The parent plant of this taxon belongs to the subfamily
Taxodiaceae of the family Cupressaceae (the cypresses) according to Van Konijnenburg-Van Cittert (1971). It has been interpreted as a thermophilic conifer tree (Vakhrameev 1991), but Abbink et al. (2004, p. 27) placed it in their Lowland Sporomorph Ecogroup as part of a cool, marshy, wet assemblage. Perinopollenites elatoides is abundant throughout the Jurassic and clearly the parent plant was common, so it is, in many ways, a background taxon. However, its consistent abundance together with Classopollis classoides and Liasidium variabile during the Liasidium Event is at least consonant with a phase of warming. The relatively high content of amorphous organic material in the simpsoni Subzone is also compatible with this hypothesis, as increased production and preservation of marine organic matter is an expected consequence of accelerated hydrological cycle and flux of nutrients to the shallow shelf settings (cf. Jenkyns 2010). 
Full/prolonged benthic anoxia was not developed during the Liasidium Event at the studied location. Therefore, Liasidium variabile was not a 'disaster species' sensu van de Schootbrugge et al. (2007). 'Disaster species' in this context are opportunistic marine palynomorph taxa (normally acritarchs and/ or prasinophytes) which thrived during geologicallybrief episodes of severe environmental stress. Separate acmes of prasinophytes and acritarchs at the Triassic-Jurassic transition $(\sim 201 \mathrm{Ma})$ in southwest England were identified by van de Schootbrugge et al. (2007, fig. 3). Those palynomorphs are part of the green algal lineage, and bloomed during a marked negative shift in $\delta^{13} \mathrm{C}_{\text {org }}$ associated with shallow marine anoxia developed at the end-Triassic mass extinction. 'Disaster species' are also prevalent during the Toarcian Oceanic Anoxic Event (T-OAE, 182 Ma). The T-OAE is the first of the sharply defined Mesozoic Oceanic Anoxic Events and dinoflagellate cysts typically disappear during it and were replaced by abundant prasinophytes which represent green algal 'disaster species' (Bucefalo Palliani et al. 2002).

Acritarchs and prasinophytes are relatively sparse during the two acmes of Liasidium variabile observed here (Supplementary Data File). Therefore, Liasidium variabile is interpreted as simply a thermophilic dinoflagellate cyst species that thrived when the palaeotemperature became elevated. In this respect, Liasidium appears to be similar to Apectodinium augustum in the Paleocene-Eocene Thermal Maximum, a species which tracked the movement of warm marine water polewards (Kender et al. 2012, Riding et al. 2013). If Liasidium variabile did move northwards into Europe during the Late Sinemurian, its southerly provenance is unclear because it is apparently absent in the Sinemurian strata of the Lusitanian Basin in Portugal (Correia at el. 2018). The latter observation suggests that Liasidium variabile may be endemic to northwest Europe. Its temporal range ascertained here appears to be robust, and its abundance may simply be linked to its increased bioproductivity associated with the relatively high palaeotemperatures reached during the Liasidium Event.

\subsection{Relative sea-level change}

The Lower Jurassic succession in the Cleveland Basin has been used to infer trends of relative sea-level change (e.g. Hesselbo 2008). For the interval of interest here, facies trends suggested relative sea-level rise throughout the time equivalent to the obtusum
Zone and lowermost oxynotum Zone, followed by relative sea-level fall through the time equivalent to the uppermost oxynotum Zone and overlying raricostatum Zone (Hesselbo and Jenkyns 1998, van Buchem and Knox 1998, Haq 2017). These inferred relative sea-level changes likely occurred simultaneously in adjacent basins, based on interpretation of facies trends and occurrences of hiatuses (Hesselbo and Jenkyns 1998, Riding et al. 2013). The new data allow a more detailed assessment of relative sea-level change through the oxynotum Zone interval.

All the measured elemental, mineralogical, and total organic carbon data show cyclicity on a scale of $\sim 2 \mathrm{~m}$ (Figs. 3-5). This is, for example, well displayed by the $\mathrm{Rb}$ content and $\mathrm{Si} / \mathrm{Al}$ ratio from the $\mathrm{HH}-\mathrm{XRF}$ dataset (Figs 4,8 ), a good proxy for sand/clay ratio. In that dataset, several $\sim 2 \mathrm{~m}$ thick coarsening-upward cycles are observed, especially in the lowest four metres and the upper half of the section; as well as matching the expected thickness for orbital short eccentricity cycles in the Robin Hood's Bay succession (Van Buchem et al. 1992), these cycles are typical parasequences (van Wagoner et al. 1990), and the inferred parasequence stacking pattern for the lower part of the succession up to the Liasidium acme conforms well to a progressively more distal setting for each parasequence (i. e., backstepping). The finest grain size and inferred most distal environment (maximum flooding surface 1 or $\mathrm{mfs} 1$ ) is developed at about $-19.3 \mathrm{~m}$, closely corresponding to one of the two distinctive nodule beds, the lower -ve CIE and a major peak in abundance of Liasidium variabile, although it is notable that there is detectable stratigraphical offset between all these features (Figs. 3-5). (Alternatively, the mfs may be recognized about $-17.8 \mathrm{~m}$ within the subsequent parasequence, where similar stratigraphic phenomena are observed; Fig. 8.)

Above, a stratigraphically abrupt shallowing is recorded in two progressively more proximal parasequence cycles that make up the lower two metres of the oxynotum Subzone and culminating at the Double Band (Fig. 4). This sediment package is sharply followed by an abrupt return to more distal facies ( $\mathrm{mfs} 2$ at about $-14.9 \mathrm{~m}$ ), and then a progressive coarsening over about three parasequence cycles (i. e., a forestepping pattern), followed by a progressive deepening (backstepping) to the top of the section studied, and into the base of the overlying raricostatum Zone.

In summary, the succession represents two subcycles within one larger scale cycle of relative sealevel change in which the deepest water phases, or maximum flooding, correspond to mass occurrences of 
Liasidium variabile. No evidence of strong condensation is observed. However, the two distinctive carbonate nodule beds (bed 39 at $-19.70 \mathrm{~m}$ and bed 41 at -17.90 m, Supplementary Fig. 1) that occur a few 10s of $\mathrm{cm}$ below the two -CIE spikes and which contain uncrushed ammonite fossils at their cores (Hesselbo and Jenkyns 1995), suggest the possibility of at least a depositional slowdown at the times of the excursions which allowed growth of the concretions at a diagenetic interface (cf. Raiswell 1987).

Maximum regression is evident at the Double Band $(-15 \mathrm{~m})$ and at the Upper Triplet $(\sim-11.5 \mathrm{~m})$. The extent to which these patterns reflect local versus regional or global sea-level changes is unknown, but the close juxtaposition of fine grained, below wave-base facies at the -ve CIEs, and the shallow water, above wave-base facies $1-2 \mathrm{~m}$ stratigraphically above is evidence that sea-level change rather than fluctuations in sediment supply was the principal factor affecting the described stratigraphical patterns. A significant hiatus at the Double Band (Fig. 3) may be suspected from the abruptness of the facies transitions, but at present is unproven. Assuming the attribution of the $\sim 2 \mathrm{~m}$ cycles to short eccentricity, following van Buchem et al. (1992), the total duration of the Liasidium Event (defined by the total range of Liasidium variabile) is estimated to be $>1 \mathrm{Myr}$.

\subsection{Early diagenetic versus detrital clay mineralogy and palaeoclimate}

The detrital silt- to sand-size mineralogy of quartz, muscovite and Mg-chlorite is consistent with derivation from Lower Paleozoic mica schist, lying to the north and west of the Cleveland Basin (Powell 2010). Most of the clay in sedimentary rocks, in general, is formed by weathering or in soils, and will reflect the prevailing climate (Chamley 1989). However, shifts in both water depth and in provenance can result in depth trends in detrital mineralogy that are not solely indicative of palaeoclimatic change (e. g. Bougeault et al. 2017). A further complication is the formation of authigenic clays. Thus, before clay mineral trends can be used to infer palaeoclimate, it is important to assess sedimentological factors (i. e. sediment source, depth of deposition) and diagenetic mineral formation.

Petrographical analysis confirms that the whole rock $\mathrm{K} / \mathrm{I}+\mathrm{IS}$ ratios from XRD measurements are due to the presence of variable, and locally high, volumes of kaolinite pseudomorphs after mica. For chlorite, the situation is more complicated: 1) silt- and sand-size
Mg-chlorite and, 2) authigenic Fe-chlorite are both observed in BSEM images (Fig. 7), and some claygrade $\mathrm{Mg}$ - or Fe-chlorite may reasonably be presumed to be a component of the detrital clay assemblage. However, it is not possible to identify these three components seperately in the XRD data, hence XRD data for chlorite are not of use here as proxies for palaeoclimate or depositional environment.

Early diagenetic assemblages, including kaolinite do, however, provide evidence of the early postdepositional environment (e.g. Chamley 1989 p. 333-358, Hurst and Irwin 1982). Within the oxynotum Zone at Robin Hood's Bay, authigenic kaolinite is the most widespread and abundant authigenic mineral. The formation of kaolinite is through replacement of muscovite, a hydrolysis reaction associated with low temperature, low salinity, or low $\mathrm{pH}$ pore fluid (Bjørlykke and Aagaard 1992, Bjørlykke 1998). Relative abundance of authigenic kaolinite amongst the clays is consequently highest where the original muscovite content was also originally highest; i. e., in the coarser grained sediment. Similarly, in silt- and sandrich intervals, where silt- and sand-size Mg-chlorite grains were formerly abundant, they have been replaced by authigenic Fe-chlorite. Fe-for-Mg replacement occurs in the chlorite because Mg-chlorite minerals are formed in metamorphic rocks, and are thermodynamically unstable in the diagenetic environment, where Fe chlorite is instead the stable form.

The relative timings of the authigenic minerals may be approximately determined from textural relationships and the geochemical requirements for their precipitation. Framboidal pyrite is characteristically early formed, as a result of bacterial sulphate and iron reduction in association with organic matter (Berner 1980, Curtis 1987). Pyrite may be contemporaneous with the widespread but minor non-ferroan dolomite, while the ferroan dolomite that overgrows the nonferroan dolomite is likely to have formed once pyrite formation ceased to be the principal consumer of Fe-II. The presence of pyrite inclusions in siderite nodules suggests that the siderite also post-dates pyrite. Authigenic Fe chlorite has filled pore space around ferroan dolomite, and infilled cracks in authigenic kaolinite aggregates (Fig. 7C, D), implying that the Fe-chlorite formation post-dates both the ferroan dolomite and the kaolinite. Authigenic chlorite is commonly associated with low-latitude shallow-marine and deltaic sediments (e. g., Imam 1989, Grigsby 2001, Bahlis and De Ros 2013,). In this instance textural relationships indicate that $\mathrm{Fe}$-chlorite formation is primarily a result 
of Mg-chlorite alteration. Epitaxial quartz cement has overgrown chlorite, indicating that it is the later cement. Significant quartz cementation occurs at temperatures in excess of $80^{\circ} \mathrm{C}$, consistent with formation having occurred during relatively deep burial, and in agreement with the burial depth estimates suggested by Kemp et al. (2005) - equivalent to $\sim 3.5-4 \mathrm{~km}$ for the middle Sinemurian.

In summary, the observed clay mineral assemblages and the paragenetic relationships provide good evidence of provenance from expected source terrains to the north and northwest. Relative abundances of kaolinite correspond to authigenic processes acting preferentially on original detrital silicates, rather than as a response to palaeoclimate. Authigenesis and burial diagenesis effects render the Robin Hood's Bay exposures of the Cleveland Basin unsuitable for the determination of weathering regimes during the Liasidium Event using clay assemblages (cf. van Buchem et al. 1992).

\section{Conclusions}

The principal characteristics of the Liasidium Event, initially based on a rudimentary dataset from eastern England, are herein confirmed and extended based on a high-resolution study of the marine succession at Robin Hood's Bay, Yorkshire, northeast England. The event is characterised by a negative carbon-isotope excursion in bulk organic matter which is resolved into a double spike. The amplitude of the negative carbon-isotope excursion (-ve CIE) in bulk organic matter is in the order of $1.5 \%$; but its occurrence in other substrates at Robin Hood's Bay has not yet been demonstrated. The negative excursion coincides with an abundance of the thermophyllic pollen grain Classopollis classoides, and the acme of the possibly heterotrophic dinoflagellate cyst Liasidium variabile. The Liasidium Event occurs during deposition of the deepest water facies within the local sequence, and corresponds to a transgressive-regressive facies cycle. Stratigraphical trends in elemental geochemistry, detrital mineralogy, and organic carbon content, together with visual description of the lithofacies, define prominent mostly shallowing-up cycles on a scale of about $2 \mathrm{~m}$. These parasequences correspond in scale to previously inferred short eccentricity cyclicity, suggesting a significant $100 \mathrm{kyr}$ astronomical control on sedimentary and stratigraphical characteristics, and a total duration of the event of $>1$ Myr. Detrital clay comprises illite and illite-smectite. Kaolinite and chlorite also both occur as detrital components, but are strongly augmented by authigenesis. Relative kaolinite peaks amongst the clay minerals in the coarser beds reflect the diagenetic alteration of mica. The Liasidium Event has only hitherto been recorded in northwest Europe; future work should attempt to ascertain if this phenomenon is present elsewhere in the world wherever marine Upper Sinemurian strata are present.

Acknowledgements. The reviews of Carmen Heunisch and an anonymous referee have markedly improved this contribution. James B. Riding and Melanie Leng publish with the approval of the Executive Director, British Geological Survey (NERC); we gratefully ackonwledge support from staff at the Bristish Geological Survey, Keyworth. The staff of the Centre for Imaging and Analysis at the Natural History Museum, London are thanked for assistance with the scanning electron microscope analyis. David Wray and Lorner Dyer of Greenwich University are thanked for collecting the X-ray diffraction data. We acknowledge funding from Shell (Oxford-Shell collaboration), the Natural Environment Research Council (NERC) [NE/N018508/1], the NERC GW4+ DTP and the Natural Environment Research Council [NE/L002434/1], and the British Geological Survey [Contract GA/16S/018]. Ullmann acknowledges funding from the Leopoldina, German National Academy of Sciences (grant no. LPDS 2014-08). This is a contribution to the JET project. Sev Kender and Marisa Storm kindly helped with sample collection in the field.

\section{References}

Abbink, O.A., Van Konijnenburg-Van Cittert, J.H.A., Visscher, H., 2004. A sporomorph ecogroup model for the Northwest European Jurassic - Lower Cretaceousi (sic.): concepts and framework. Netherlands Journal of Geosciences/Geologie en Mijnbouw 83, 17-38.

Bahlis, A. B., De Ros, L.F., 2013. Origin and impact of authigenic chlorite in the Upper Cretaceous sandstone reservoirs of the Santos Basin, eastern Brazil. Petroleum Geoscience 19, 185-199.

Berner, R. A., 1980. Early Diagenesis. A Theoretical Approach, Princeton University Press, Guildford, 241 pp.

Bjerrum, C. J., Surlyk, F., Callomon, J.H., Slingerland, R. L., 2001. Numerical paleoceanographic study of the Early Jurassic transcontinental Laurasian Seaway. Paleoceanography $16,390-404$.

Bjørlykke, K., 1998. Clay mineral diagenesis in sedimentary basins a key to the prediction of rock properties. Examples from the North Sea Basin. Clay Minerals 33, 15-34.

Bjørlykke, K., Aagaard, P., 1992. Clay Minerals in North Sea Sandstones. In: Houseknecht, D. W., Pittman, E. D. (Eds.), Origin, Diagenesis, and Petrophysics of Clay 
Minerals in Sandstones. Society of Economic Paleontologists and Mineralogists Special Publication 47, 65-80.

Bougeault, C., Pellenard, P., Deconinck, J.-F., Hesselbo, S. P., Dommergues, J.-L., Bruneau, L., Cocquerez, T., Laffont, R., Huret, E., Thibault, N., 2017. Climatic and palaeoceanographic changes during the Pliensbachian (Early Jurassic) inferred from clay mineralogy and stable isotope (C-O) geochemistry (NW Europe). Global and Planetary Change 149, 139-152.

Brittain, J. M., Higgs, K. T., Riding, J. B., 2010. The palynology of the Pabay Shale Formation (Lower Jurassic) of SW Raasay, northern Scotland. Scottish Journal of Geology 46, 67-75.

Bucefalo Palliani, R., Mattioli, E., Riding, J. B., 2002. The response of marine phytoplankton and sedimentary organic matter to the early Toarcian (Lower Jurassic) oceanic anoxic event in northern England. Marine Micropaleontology 46, 223-245.

Bucefalo Palliani, R., Riding, J. B., 2000. A palynological investigation of the Lower and lowermost Middle Jurassic strata (Sinemurian to Aalenian) from North Yorkshire, UK. Proceedings of the Yorkshire Geological Society 53, $1-16$.

Buckman, S. S., 1915. A palaeontological classification of the Jurassic rocks of the Whitby district; with a zonal table of the ammonites. In: Fox-Strangways, C., Barrow, G. (Eds.), The Geology of the Country between Whitby and Scarborough: Memoirs of the Geological Survey of Great Britain, 59-102.

Bujak, J. P., Davies, E. H., 1993. Modern and fossil Peridiniineae. American Association of Stratigraphic Palynologists Contributions Series 13, 203 p.

Busfield, M. E., Lee, J. R., Riding, J. B., Zalasiewicz, J., Lee, S. V., 2015. Pleistocene till provenance in east Yorkshire: reconstructing ice flow of the British North Sea Lobe. Proceedings of the Geologists' Association 126, 86-99.

Calvert, S.E., Pedersen, T.F., 2007. Chapter Fourteen. Elemental Proxies for Palaeoclimatic and Palaeoceanographic Variability in Marine Sediments: Interpretation and Application. In: Hillaire-Marcel, C., De Vernal, A. (Eds.), Developments in Marine Geology 1, 567-644.

Chamley, H., 1989. Clay Sedimentology, Springer-Verlag, Berlin.

Clayton, G., Coquel, R., Doubinger, J., Gueinn, K. J., Loboziak, S., Owens, B., Streel, M., 1977. Carboniferous miospores of Western Europe: Illustration and zonation. Mededelingen Rijks Geologische Dienst 29, 71 p.

Cope, J. C. W., Ingham, J. K., Rawson, P. F. (Eds.), 1992. Atlas of Palaeogeography and Lithofacies, Geological Society, London, Memoirs, 13.

Correia, V.F., Riding, J. B., Duarte, L. V., Fernandes, P., Pereira, Z., 2018. The Early Jurassic palynostratigraphy of the Lusitanian Basin, western Portugal. Geobios, doi: 10.1016/j.geobios.2018.03.001.

Coward, M.P., Dewey, J.F., Hempton, M., Holroyd, J., 2003. Tectonic evolution. In: Evans, D., Graham, C., Armour, A., Bathurst, P. (Eds.), The Millennium Atlas:
Petroleum Geology of the Central and Northern North Sea, The Geological Society of London, London, 17-33.

Curtis, C. D., 1987. Mineralogical Consequences of Organic Matter Degradation in Sediments: Inorganic/Organic Diagenesis. In: Leggett, J. K., Zuffa, G. G. (Eds.), Marine Clastic Sedimentology, Graham and Trotman, London, 108-123.

Dera, G., Pucéat, E., Pellenard, P., Neige, P., Delsate, D., Joachimski, M. M., Reisberg, L., Martinez, M., 2009. Water mass exchange and variations in seawater temperature in the NW Tethys during the Early Jurassic: Evidence from neodymium and oxygen isotopes of fish teeth and belemnites. Earth and Planetary Science Letters 286, 198-207.

Drugg, W. S., 1978. Some Jurassic dinoflagellate cysts from England, France and Germany. Palaeontographica Abteilung B 168, 61-79.

Duarte, L. V., Comas-Rengifo, M. J., Silva, R. L., Parades, R., Goy, A., 2014. Carbon isotope stratigraphy and ammonite biochronostratigraphy across the Sinemurian-Pliensbachian boundary in the western Iberian margin. Bulletin of Geosciences 89, 719-736.

Feist-Burkhardt, S., 2009. Palynology of the Sinemurian/ Pliensbachian boundary (Lower Jurassic) in the Wutach area, SW Germany: dinoflagellate cyst systematics, biostratigraphy and heterotrophic character of Liasidium variabile. Neues Jahrbuch für Geologie und Paläntologie Abhandlungen 254, 293-313.

Franceschi, M., Dal Corso, J., Posenato, R., Roghi, G., Masetti, D., Jenkyns, H. C., 2014. Early Pliensbachian (Early Jurassic) C-isotope perturbation and the diffusion of the Lithiotis Fauna: insights from the western Tethys. Palaeogeography, Palaeoclimatology, Palaeoecology 410, 255-263.

Gradstein, F. M., Ogg, J. G., Schmitz, M.D., Ogg, G. M., 2012. The Geologic Time Scale 2012, 2, Elsevier, Oxford, UK.

Grigsby, J.D., 2001. Origin and growth mechanism of authigenic chlorite in sandstones of the Lower Vicksburg Formation, South Texas. Journal of Sedimentary Research 71, 27-36.

Hamon, Y., Merzeraud, G., 2007. C and O isotope stratigraphy in shallow-marine carbonate: a tool for sequence stratigraphy (example from the Lodève region, peritethian domain). Swiss Journal of Geosciences 100, 71-84.

Haq, B., 2017. Jurassic sea-level variations: a reappraisal. GSA Today 28, 4-10.

Head, M. J.Harland, R., 2013. A history of the International Conferences on Modern and Fossil Dinoflagellates, 1978-2011. In: Lewis, J.M., Marret, F., Bradley, L. (Eds.), Biological and Geological Perspectives of Dinoflagellates. The Micropalaeontological Society, Special Publications, Geological Society, London, 1-21.

Hedges, J. I., Keil, R. G., Benner, R., 1997. What happens to terrestrial organic matter in the ocean? Organic Geochemistry $27,195-212$. 
Hesselbo, S. P., 2008. Sequence stratigraphy and inferred relative sea-level change from the onshore British Jurassic. Proceedings of the Geologists' Association 119, 19-34.

Hesselbo, S. P., Jenkyns, H. C., 1995. A comparison of the Hettangian to Bajocian successions of Dorset and Yorkshire. In: Taylor, P. D. (Ed.), Field Geology of the British Jurassic, Geological Society, London, 105-150.

Hesselbo, S. P., King, C., 2019. Stratigraphic Framework for the Yorkshire Lias. In: Lord, A. (Ed.), Fossils of the Lias of Yorkshire, Palaeontological Association, In press.

Howard, A.S., 1985. Lithostratigraphy of the Staithes Sandstone and Cleveland Ironstone formations (Lower Jurassic) of north-east Yorkshire. Proceedings of the Yorkshire Geological Society 45, 261-275.

Howarth, M. K., 1955. Domerian of the Yorkshire coast. Proceedings of the Yorkshire Geological Society 30, 147-175.

Howarth, M. K., 2002. The Lower Lias of Robin Hood's Bay, Yorkshire, and the work of Leslie Bairstow. Bulletin of the Natural History Museum, London (Geology Series) 58 (2), 81-152.

Hurst, A., Irwin, H., 1982. Geological modelling of clay diagenesis in sandstones. Clay Minerals 17, 5-23.

Imam, M. B., 1989. Comparison of burial diagenesis in some deltaic to shallow marine reservoir sandstones from different basins. Journal of the Geological Society of India 33, 524-537.

Jeans, C. V., 2006. Clay mineralogy of the Jurassic strata of the British Isles. Clay Minerals 41, 4-150.

Jenkyns, H. C., 2010. Geochemistry of oceanic anoxic events. Geochemistry, Geophysics, Geosystems 11, Q03004.

Jenkyns, H.C., Weedon, G. P., 2013. Chemostratigraphy $\left(\mathrm{CaCO}_{3}, \mathrm{TOC}, \delta^{13} \mathrm{C}_{\text {org }}\right.$ ) of Sinemurian (Lower Jurassic) black shales from the Wessex Basin, Dorset and palaeoenvironmental implications. Newsletters on Stratigraphy 46, 1-21.

Katz, M.E., Wright, J.D., Miller, K. G., Cramer, B.S., Fennel, K., Falkowski, P. G., 2005. Biological overprint of the geological carbon cycle. Marine Geology 217, 323-338.

Kemp, S. J., Merriman, R.J., Bouch, J.E., 2005. Clay mineral reaction progress - the maturity and burial history of the Lias Group of England and Wales. Clay Minerals 40, 43-61.

Kender, S., Stephenson, M. H., Riding, J. B., Leng, M. J., Knox, R. W. O'B, Peck, V.L., Kendrick, C. P., Ellis, M.A., Vane, C.H., Jamieson, R., 2012. Marine and terrestrial environmental changes in NW Europe preceding carbon release at the Paleocene-Eocene transition. Earth and Planetary Science Letters 353-354, 108-120.

Korte, C., Hesselbo, S. P., 2011. Shallow-marine carbon- and oxygen-isotope and elemental records indicate icehousegreenhouse cycles during the Early Jurassic. Paleoceanography 26, doi: https://doi.org/10.1029/2011PA002160.

Lee, J. R., Rose, J., Riding, J. B., Moorlock, B. S. P., Hamblin, R. J. O., 2002. Testing the case for a Middle Pleistocene Scandinavian glaciation in Eastern England: Evi- dence for a Scottish ice source for tills within the Corton Formation of East Anglia, UK. Boreas 31, 345-355.

Masetti, D., Figus, B., Jenkyns, H. C., Barattolo, F., Mattioli, M., Posenato, R., 2016. Carbon-isotope anomalies and demise of carbonate platforms in the Sinemurian (Early Jurassic) of the Tethyan region: evidence from the Southern Alps (Northern Italy). Geological Magazine 154, 625-650.

McIlroy, D., 2007. Lateral variability in shallow marine ichnofabrics: implications for the ichnofabric analysis method. Journal of the Geological Society of London 164, 359-369.

Peti, L., Thibault, N., Clémence, M.-E., Korte, C., Dommergues, J.-L., Bougeault, C., Pellenard, P., Jelby, M. E., Ullmann, C. V., 2017. Sinemurian-Pliensbachian calcareous nannofossil biostratigraphy and organic carbon isotope stratigraphy in the Paris Basin: calibration to the ammonite biozonation of NW Europe. Palaeogeography, Palaeoclimatology, Palaeoecology 468, 142-161.

Porter, S. J., Smith, P. L., Caruthers, A. H., Hou, P., Gröcke, D. R., Selby, D., 2014. New high resolution geochemistry of Lower Jurassic marine sections in western North America: A global positive carbon isotope excursion in the Sinemurian? Earth and Planetary Science Letters 397, 19-31.

Powell, J. H., 2010. Jurassic sedimentation in the Cleveland Basin: a review. Proceedings of the Yorkshire Geological Society 58, 21-72.

Raiswell, R., 1987. Non-steady state microbiological diagenesis and the origin of concretions and nodular limestones. In: Marshall, J. D. (Ed.), Diagenesis of Sedimentary Sequences, Geological Society, London, Special Publication 36, 41-54.

Riding, J. B., 1987. Dinoflagellate cyst stratigraphy of the Nettleton Bottom Borehole (Jurassic: Hettangian to Kimmeridgian), Lincolnshire, England. Proceedings of the Yorkshire Geological Society 46, 231-266.

Riding, J. B., Kyffin-Hughes, J. E., 2004. A review of the laboratory preparation of palynomorphs with a description of an effective non-acid technique. Revista Brasileira de Paleontologia 7, 13-44.

Riding, J. B., Leng, M. J., Kender, S., Hesselbo, S. P., FeistBurkhardt, S., 2013. Isotopic and palynological evidence for a new Early Jurassic environmental perturbation. Palaeogeography, Palaeoclimatology, Palaeoecology 374, 16-27.

Riding, J. B., Rose, J., Booth, S. J., 2003. Allochthonous and indigenous palynomorphs from the Devensian of the Warham Borehole, Stiffkey, north Norfolk, England; evidence for the sediment provenance. Proceedings of the Yorkshire Geological Society 54, 223-237.

Sellwood, B. W., 1970. The relation of trace fossils to small scale sedimentary cycles in the British Lias. In: Crimes, T. R., Harper, J.C. (Eds.), Trace Fossils: Geological Journal Special Issue 3, 489-504.

Smith, A. V. H., Butterworth, M. A., 1967. Miospores in the coal seams of the Carboniferous of Great Britain. Special Papers in Palaeontology 1, 324 p. 
Srivastava, S. K., 1987. Jurassic spore-pollen assemblages from Normandy (France) and Germany. Géobios 20, $5-79$.

Srivastava, S. K., 2011. Spore-pollen biostratigraphy of the English Jurassic. Palaeontographica Abteilung B 285, 113-201.

Tyson, R. V., 1995. Sedimentary Organic Matter: Organic Facies and Palynofacies, Chapman and Hall, London, $615 \mathrm{pp}$.

Vakhrameev, V. A., 1991. Jurassic and Cretaceous floras and climates of the Earth, Cambridge University Press, Cambridge, $318 \mathrm{pp}$.

van Buchem, F. S. P., Knox, R. W.O’B., 1998. Lower and Middle Jurassic depositional sequences of Yorkshire (UK). In: de Graciansky, P. C., Hardenbol, J., Jacquin, T., Vail, P. R. (Eds.), Mesozoic-Cenozoic Sequence Stratigraphy of European Basins: Society of Economic Paleontologists and Mineralogists. Special Publications 60, 545-559.

van Buchem, F. S. P., McCave, I. N., 1989. Cyclic sedimentation patterns in Lower Lias mudstones of Yorkshire (GB). Terra Nova 1, 461-467.

van Buchem, F. S. P., Melnyk, D. H., McCave, I. N., 1992. Chemical cyclicity and correlation of the Lower Lias mudstone using gamma ray logs, Yorkshire, UK. Journal of the Geological Society of London 149, 991-1002.

van de Schootbrugge, B., Richoz, S., Pross, J., Luppold, F. W., Hunze, S., Wonik, T., Blau, T., Meister, C., van der Weijst, C. M. H., Suan, G., Fraguas, A., Fiebig, J., Herrle, J. O., Guex, J., Little, C. T.S., Wignall, P. B., Püttmann, W., Oschmann, W., 2019. The Schandelah Scientific Drilling Project: A 25-million year record of Early Jurassic palaeo- environmental change from northern Germany. Newsletters on Stratigraphy 52 (3), 249-296, doi: https://doi.org/10.1127/nos/2018/0259.

van de Schootbrugge, B., Tremolada, F., Rosenthal, Y., Bailey, T. R., Feist-Burkhardt, S., Brinkhuis, H., Pross,
J., Kent, D. V., Falkowski, P. G., 2007. End-Triassic calcification crisis and blooms of organic-walled 'disaster species'. Palaeogeography, Palaeoclimatology, Palaeoecology 244, 126-141.

Van Konijnenburg-Van Cittert, J. H. A., 1971. In situ gymnosperm pollen from the Middle Jurassic of Yorkshire. Acta Botanica Neerlandica 20, 1-97.

Van Wagoner, J.C., Mitchum, R. M., Campion, K. M., Rahmanian, V. D., 1990. Siliciclastic Sequence Stratigraphy in Well Logs, Cores and Outcrops. Tulsa, American Association of Petroleum Geologists Methods in Exploration Series 7, 55 pp.

Weiss, M., 1989. Die Sporenfloren aus Rät und Jura Südwest-Deutschlands und ihre Beziehung zur Ammoniten-Stratigraphie. Palaeontographica Abteilung B 215, $1-168$.

Woodland, A. W., 1971. The Llanbedr (Mochras Farm) Borehole, Report No. 71/18, Institute of Geological Sciences, $115 \mathrm{pp}$.

Wotzlaw, J.-F., Guex, J., Bartolini, A., Gallet, Y., Leopold Krystyn, L., McRoberts, C. A., Taylor, D., Blair Schoene, B., Schaltegger, U., 2014. Towards accurate numerical calibration of the Late Triassic: High-precision U-Pb geochronology constraints on the duration of the Rhaetian. Geology 42, 571-574.

Ziegler, P. A., 1990. Geological Atlas of Western and Central Europe. Second Edition. Shell International Petroleum Maatschappij, Drukkerij Verweij B. V., Mijdrecht, 238 pp.

Manuscript received: January 02, 2019

Revisions required: February 04, 2019

Revised version received: March 19, 2019

Manuscript accepted: March 21, 2019

\section{Appendix 1}

This appendix lists all nomenclaturally valid palynomorph taxa below generic level which are mentioned in this contribution with full author citations. The species are listed alphabetically within three groups. Reworked Carboniferous spores are indicated with an asterisk.

\section{Aquatic palynomorphs:}

Botryococcus braunii Kützing 1849

Liasidium variabile Drugg 1978

Rhaetogonyaulax rhaetica (Sarjeant 1963) Loeblich Jr. \& Loeblich III 1968

Veryhachium collectum Wall 1965 


\section{Gymnospermous pollen:}

Araucariacites australis Cookson 1947

Cerebropollenites macroverrucosus (Thiergart 1949) Schulz 1967

Classopollis classoides (Pflug 1953) Pocock \& Jansonius 1961

Perinopollenites elatoides Couper 1958

Vitreisporites pallidus (Reissinger 1950) Nilsson 1958

\section{Pteridophyte spores:}

Coronatispora valdensis (Couper 1958) Dettmann 1963

Cyathidites australis Couper 1953

Cyathidites minor Couper 1953

Kraeuselisporites reissingeri (Harris 1957) Morbey 1975

*Lycospora pusilla (Ibrahim 1932) Schopf et al. 1944

Retitriletes austroclavatidites (Cookson 1953) Döring et al. 1963

*Tripartites trilinguis (Horst 1943) Potonié \& Kremp 1955

*Tripartites vetustus Schemel 1950

Zebrasporites interscriptus (Thiergart 1949) Klaus 1960

\section{The pdf version of this paper includes an electronic supplement}

Please save the electronic supplement contained in this pdf-file by clicking the blue frame above. After saving rename the file extension to .zip (for security reasons Adobe does not allow to embed .exe, .zip, rar etc. files).

\section{Table of contents - Electronic Supplementary Material (ESM)}

Supplementary Figure 1. A detailed sedimentary log of the Siliceous Shale Member at Robin Hood's Bay, Yorkshire, showing the positions of all the samples and the ammonite biostratigraphy of Howarth (2002).

Supplementary Figure 2. Graphic log for the mid-Sinemurian at Robin Hood's Bay with the stratigraphical distributions of selected palynomorphs. Data are plotted as \% of particle counts and the ratios are of particle numbers. AOM = Amorphous Organic Matter.

Supplementary Data File. BGS lab data. Carbon-isotope, TOC, C/N ratios.

Supplementary Data File. Palynology. The distribution of palynomorphs in the 60 samples studied. The taxa are subdivided into four groups, i. e. pteridophyte spores, gymnosperm pollen, aquatic palynomorphs (acritarchs, dinoflagellate cysts etc.) and reworked palynomorphs. The allochthonous palynomorphs are all Mississippian/Pennsylvanian except for the Permian saccate pollen and the Triassic dinoflagellate cyst Rhaetogonyaulax rhaetica. The numbers are the respective absolute totals within the grain count for that sample. An " $\mathrm{X}$ " indicates that the respective palynomorph is present, but was not encountered in the count. An ellipsis (...) means that the respective palynomorph is absent. A question mark (?) denotes that that the identification of the taxon is equivocal. The four columns on the right are the percentages of the four principal kerogen macerals (i. e. wood, other plant tissues, palynomorphs and amorphous organic matter).

Supplementary Data File. Hand-held XRF data.

Supplementary Data File. Hand-held XRF standards.

Supplementary Data File. Whole rock XRD data. 